\title{
The Significance of Institutional Culture in Enhancing the Validity of International Criminal \\ Tribunals
}

\section{Hemi Mistry*}

\section{Keywords}

Collegiality, judicial decision-making, dissent, ICC, deliberations, culture, ICJ

\begin{abstract}
When considering the validity of international criminal tribunals, focus is typically and appropriately upon areas of substantive law and procedure and questions of prosecutorial policy. However, to the extent that it is within the capacity of judges to address and resolve challenges to the validity of the institution, in order for judges to formulate and implement effective solutions to those challenges it is imperative that an institutional culture is cultivated that is conducive to those ends. This paper explains the relationship between judicial culture and institutional legitimacy, and highlights how recent jurisprudence of the International Criminal Court (ICC) suggests that there is a need for the adoption and implementation of measures to promote the development of a robust institutional culture conducive to resolving the challenges faced by the ICC.
\end{abstract}

\section{Introduction}

Different factors - legal, political, moral and philosophical - may give cause to question the validity of the ICC and the international criminal justice enterprise. Other contributors to this collection address many of those. Some fall - to varying degrees - within the capacity of ICC

\footnotetext{
* Assistant Professor, School of Law, University of Nottingham. The author would like to thank PluriCourts - the organisers - of the conference entitled 'Strengthening the Validity of International Criminal Tribunals' (29-30 August 2016, Oslo) and participants for their valuable comments on the presentation upon which this paper is based. The author can be contacted at hemi.mistry@ nottingham.ac.uk.
} 
judges to address, while some are beyond their remit. To the extent that it is within the capacity of ICC judges to address a given issue, in order to do so effectively and efficiently it is imperative that ICC judges develop an institutional culture conducive to that end. One such culture is that of collegiality. 1 This paper outlines the meaning and significance of the concept of collegiality before focusing upon two issues that have been recently addressed by ICC judges that have implications for the Court's validity. It will focus upon three decisions of the ICC Chambers: the judgment of Trial Chamber II in Katanga, ${ }^{2}$ the judgment of the Appeals Chamber in Ngudjolo Chui, ${ }^{3}$ and, most recently, the decision of Trial Chamber VA in Ruto and Sang. ${ }^{4}$ The issue raised and addressed by the judgments in the former two cases concern fundamental methodological questions of fact-finding and the development of an effective and efficient procedural regime, the determination of which goes to the core of the essential purpose of the trial. The latter judgment - in Ruto and Sang - touches upon the core issue of how ICC judges can and should use their powers in order to respond to external challenges to the institution's legitimacy and actions of third parties designed to frustrate the judicial process. All of these decisions are characterised by certain weaknesses of form and substance that may be indicative (and a consequence) of dysfunction in the culture of collegiality among ICC judges. Further research is required in order to determine whether this recent jurisprudence is evidence of isolated instances of weaknesses in collegiality or whether it is evidence of a chronic cultural problem. Indeed, the majority of the ICC's decisions and judgments do not give any cause to question the extent of collegiality among judges. Nevertheless at a minimum,

\footnotetext{
${ }^{1}$ It should be noted that the use of 'collegiality' in the context of organisational design and culture may differ also from everyday, or ordinary usage of the term. Alan Paterson, Final Judgment: The Last Law Lords and the Supreme Court (Hart, Oxford, 2013), p.142.

2 Prosecutor v. Katanga, 8 March 2014, ICC, Trial Chamber II, Jugement Rendu en Application de l'Article 74 du Statut, ICC-01/04-01/07-3436-AnxI.

${ }^{3}$ Prosecutor v. Ngudjolo Chui, 27 February 2015, ICC, Appeals Chamber, Judgment on the Prosecutor's Appeal Against the Decision of Trial Chamber II Entitled "Judgment Pursuant to Article 74 of the Statute, ICC-01/0402/12-271-AnxA.

${ }^{4}$ Prosecutor v. William Samoei Ruto and Joshua Arap Sang, 5 April 2016, ICC, Trial Chamber V(a), Decision on Defence Applications for Judgments of Acquittal, ICC-01/09-01/11-2027-Red-Corr.
} 
the particular decisions highlight the relationship between the internal institutional culture and the institution's external legitimacy, and through them, we can see how defects in the strength of collegiality can have negative consequences upon the validity of the institution.

It may be expected that, having identified a (potential) problem, recommendations or suggestions concerning how to address that problem will follow. While it may be possible to look to other judicial institutions to identify examples of best practice from which the ICC may learn as it develops its own culture, caution must be exercised before transplanting those practices into the context of the ICC. Thus, this paper argues that the responsibility for determining which cultural practices are appropriate for the ICC lies squarely upon judges within the institution itself. However, for reasons that are explained, it is imperative that this responsibility is discharged if the Court is going to maximise its credibility as a permanent authority on the international legal and political landscape.

\section{Institutional Culture: Collegiality}

For the purposes of this analysis, 'culture' consists of the values and norms, practices, attitudes and opinions 'that are meaningful to a group of people ... and which allows them to carry out their collective lives in relative order and harmony'. Thus, culture can have both behavioural and 'ideational' aspects; it can include formal practices, traditions or procedures and it can include more substantive values and norms. ${ }^{6}$ By definition, the specific attributes of the culture within any given institution will have a direct impact upon the day-to-day effectiveness and efficiency of the activities undertaken therein and pursuant to the overall aims and objectives of the institution.

\footnotetext{
${ }^{5}$ Moshe Hirshe, An Invitation to the Sociology of International Law (Oxford University Press, Oxford, 2015), p.6; David Nelken, 'Towards a Sociology of Legal Adaptation' in David Nelken and Johannes Feest Eds, Adapting Legal Cultures (Hart, Oxford, 2001), p.25.

${ }^{6}$ Roger Cotterrell, Law, Culture and Society: Legal Ideas in the Mirror of Social Theory (Ashgate, Farnham, 2006), p.83 referring to L. Friedman, Law and Society: An Introduction (Prentice Hall, New Jersey, 1977$)$, p.76.
} 
One type of culture associated with judicial institutions is that of collegiality. The culture of collegiality is manifested in a number of formal and informal ways. Writings on collegiality as a normative concept in the judicial context can be split into those that focus on the formal principle of collegiality and those that focus on behavioural or ideational notion of collegiality. Yet, the adoption of either conception of collegiality is premised upon the same perception that processes of decision-making operating within a collegial culture are more legitimate, and thus authoritative, than processes governed by other norms.

The formal manifestation of collegiality is perhaps most associated with Max Weber's 'principle of collegiality'. ${ }^{7}$ The most relevant of Weber's 13 variations of collegiality to international judicial institutions is 'functional collegiality', according to which the acts of a non-monocratic authority

must be carried out only after previous consultation and vote. That is, their acts are subject to the rule that a plurality of individuals must cooperate for the act to be valid ... This cooperation may follow $(\alpha)$ the principle of unanimity or $(\beta)$ of decision by majority. ${ }^{8}$

This definition corresponds with the basic picture of judicial decision-making on multimember courts or tribunals where the decision of the institution is taken collectively by two or more judges. Whereas Weber's remarks on collegiality are relatively few and largely confined to predicting the general retreat from collegiality in favour of bureaucratization in social and political life, ${ }^{9}$ subsequent social theorists have elaborated upon collegiality, indicating a

\footnotetext{
${ }^{7}$ Max Weber, Economy and Society: An Outline of Interpretive Sociology Volume One (University of California, Press, California, 1978), pp.277-278.

${ }^{8}$ Ibid.

${ }^{9}$ Ibid.
} 
qualitative dimension to the legitimacy of collegially-structured organisations. ${ }^{10}$ Thus, Michael Waters has defined collegially organised structures as those

in which there is dominant orientation to a consensus achieved between members of a body of experts who are theoretically equal in their levels of expertise but who are specialised by areas of expertise. ${ }^{11}$

Proponents of this formal conception of collegiality have situated the principle at the heart of the administration of justice within some legal systems: citing the adage 'juge unique, juge inique', they argue that it gives effect to individual rights to a fair trial, and the basic tenets of deliberative democracy. ${ }^{12}$ According to Fabrice Hourquebie, the operation of collegiality in this form has institutional functions, which together strengthen the legitimacy and - in turn authority of judicial decisions rendered by collegially organised institutions. ${ }^{13}$ Hourquebie links collegiality with 'legitimate rationality'; it permits the institutionalisation of deliberation that in turn 'enables the synergy of legitimate skills (what might be called the principle of trust) and comprehensive intelligence (the principle of effectiveness) ${ }^{,} \cdot{ }^{14}$ By facilitating deliberation, collegiality 'offers space, not only for the plurality of views, but for the pluralism of ideas and points of views that exist and are part of a functioning democratic order' ${ }^{15}$ At the same time, collegiality has a moderating effect: the confrontation of opposing views in the course of deliberation confines the exercise of power. Individual decision-makers are required to cooperate in the search for consensus, which in turn limits the power of any given individual

\footnotetext{
${ }^{10}$ Michael Waters, 'Collegiality, Bureaucratization, and Professionalization: A Weberian Analysis' 54 American Journal of Sociology (1989) 945.

${ }^{11}$ Ibid., p.966 (italics added).

${ }^{12}$ Marie-Anne Cohendet, 'Law Collégialité des Juridictions: Un Principe en Voie de Disparition?' (2006) 68 Revue française de droit constitutionnel 713, p.721.

${ }^{13}$ Fabrice Hourquebie, 'La Collégialité: Valeur ou Principe?' in Jean-Jacques Menuret and Charles Reiplinger (Eds) La Collégialité, Valeurs et Significations en Droit Public (Bruylant, Brussels, 2012) and generally, Fabrice Hourquebie (Ed), Principle de collégialite et cultures judicaire (Bruylant, Brussels, 2010).

${ }^{14}$ Hourquebie, supra note 13 , p.16 translated by the author.

15 Ibid.
} 
participant in the process. ${ }^{16}$ In sum, collegiality enhances the rationality of decisions reached, thereby strengthening their perceived quality and ultimately their legitimacy and that of the institution that renders them. ${ }^{17}$

As to the specific claims regarding the importance of collegiality to vindicating fair trial rights, collegiality has positive effects upon the independence and impartiality of decision-making. From the perspective of impartiality, the collegial form of decision-making requires a process of deliberation that neutralises the effect of individual partiality by reorienting deliberation towards the formation of a general or objective decision of a disembodied institution rather than of a collective of individuals. ${ }^{18}$ By contrast, 'independence' is externally oriented and concerns the ability of decision-makers to make decisions "without any restrictions, improper influences, inducements, pressures, threats or interferences, direct or indirect, from any quarter or for any reason' ${ }^{19}$ Institutionalised collegiality shields decision-makers from pressures from external forces. ${ }^{20}$ At the institutional level, a single judge may be more susceptible to external pressures that may improperly influence their decision-making, whereas a collegial body is better equipped to withstand any such pressure. ${ }^{21}$ At the individual level, the principle of collegiality safeguards the freedom of individual judges to arrive at a decision on behalf of the court or tribunal. It does so by, in essence, distributing or diluting the responsibility severally across the members of the court or tribunal for decisions likely to be unpopular or to displease rather than placing the responsibility of that decision on the shoulders of a single judge. ${ }^{22}$

\footnotetext{
${ }^{16}$ Ibid., p.18 translated by the author.

${ }^{17}$ Ibid., p.16 translated by the author.

${ }^{18}$ Ibid., p.17 translated by the author.

${ }_{19}$ Principle 2, UN Basic Principles on the Independence of the Judiciary, endorsed by UN General Assembly Resolutions 40/32 29 November 1985 and 40/146 13 December 1985.

${ }^{20}$ Hourquebie, supra note 13 , p.17 translated by the author.

${ }^{21}$ Cohendet, supra note 12, p.720; Franklin Kuty, L'impartialité du juge en procedure pénale: De la confiance décrétée à la fiancénce justifée (Larcier, Brussels, 2005), p.161.

${ }^{22}$ Kuty, supra note 21, p.161; Cohendet, supra note 12, pp.719-720; Eva Steiner, French Law: A Comparative Approach (Oxford University Press, Oxford, 2010), p.283.
} 
Turning to the 'ideational' conception of collegiality, the focus here is less upon the formal structure of decision-making and more on the substantive quality of the relationship between judges within a collegially organised institution. The most well developed articulation of the culture of collegiality is found in the context of the US legal system. Here, Frank Coffin, a former US Federal Judge defined collegiality as

[t]he deliberately cultivated attitude among judges of equal status and sometimes widely differing views working in intimate, continuing, open and noncompetitive relationship with one another, which manifests respect for the strengths of others restrains one's pride of authorship, which respecting one's own deepest convictions, values patience in understanding and compromise in nonessentials, and seeks as much excellence in the court's decision as the combined talents, experience, insight, and energy of the judges permit. ${ }^{23}$

Another similar and similarly well-regarded definition of collegiality within the context of the US echoes many of these sentiments. Harry Edwards, former Federal Circuit Judge, defined collegiality as

judges hav[ing] a common interest, as members of the judiciary, in getting the law right, and that, as a result, we are willing to listen, persuade and be persuaded, all in an atmosphere of civility and respect. ${ }^{24}$

Accordingly, from a collective or institutional perspective the culture of collegiality may be encapsulated by the notion of an esprit d' corp. Owing to the shared commitment to 'getting it right', the culture of collegiality requires - not only tolerates - lively, tolerant, and thoughtful debate, described by one Federal Circuit Judge as 'comfortable controversy'. ${ }^{25}$ Like the formal

\footnotetext{
${ }^{23}$ Frank Coffin, On Appeal: Courts, Lawyering, and Judging (W.W. Norton, London, 1994), p.215.

${ }^{24}$ Harry Edwards, 'The Effects of Collegiality on Judicial Decision-Making' 151 University of Pennsylvania Law Review (2003) 1639, p.1645.

${ }^{25}$ Deanell Tacha,'The “C” Word: On Collegiality' 56 Ohio State Law Journal (1995) 585, p.587.
} 
conception of collegiality, this conception of collegiality has implications for the quality and legitimacy of decision-making by the collegial body. Edwards described collegiality as a synergistic force that enables individual judges on a multi-judge panel to come together and to arrive at a decision that is of 'greater value' than any one of their individual 'predilictions in decision making'. ${ }^{26}$ When present a culture of collegiality 'helps to create the conditions for principled agreement, by allowing all points of view to be aired and considered' ${ }^{27}$

Thus, the rationale for the cultivation of a culture of collegiality is clear. Theoretically it is perceived to have a positive impact upon the legitimacy of a judicial institution. For the purposes of this paper, legitimacy can be described as the 'acceptance of a body by its constituency' ${ }^{28}$ As explained by Antonio Cassese, acceptance of an institution is important because with it, it 'may obtain respect for, and compliance with, its commands without resort to force' ${ }^{29}$ Owing to the decentralised nature of international law, the juridical power of international courts and tribunals (the 'capacity to administer and enact the rules of procedure and norms and the motivational intent to secure and preserve the governing values, principles, and norms of the societal order' $)^{30}$ is dependent upon cooperation by dominant actors (typically states, but increasingly non-state actors) and their perceived legitimacy. ${ }^{31}$ There are a variety of different bases for acceptance, and thus legitimacy, and collegiality as described in this section affects the acceptance of the institution and its decisions in a number of ways. The form of collegial decision-making - that is, that it requires the participation of multiple decision makers in the deliberative and decision-making process - can strengthen the representational legitimacy of the institution and the due-process legitimacy of the institution (by promoting the

\footnotetext{
${ }^{26}$ Edwards, supra note 24, pp.1639-1940.

${ }^{27}$ Ibid., p. 1645.

28 Antonio Cassese, 'The Legitimacy of International Criminal Tribunals and the Current Prospects of International Criminal Justice' 25 Leiden Journal of International Law (2012) 491, p.492.

${ }^{29}$ Ibid.

${ }^{30}$ Steven Roach, Politicizing the International Criminal Court: The Convergence of Politics, Ethics, and Law (Rowman and Littlefield, Maryland, 2006), p.3.

${ }^{31}$ Ibid., p.3.
} 
independence and impartiality of decision-making). However, as explained in this section, the impact of collegiality is not limited to formal grounds for legitimacy: both the principle of collegiality and the ideational or behavioural conception of collegiality have positive effects upon the substantive quality of judicial decision-making and judicial reasoning that is the outcome of the process.

To conclude this section, it can be said that the cultivation of a culture of collegiality within the judicial chambers of the ICC is one way in which the Court's judges can enhance the likelihood that both the Court as an institution and its individual decisions are accepted as legitimate. The following section will first consider the extent to which the existence of collegiality is evident, and second will highlight how the jurisprudence of the Court can give reason to question the strength of collegiality. In the course of doing so, it will explain how these particular instances demonstrate the manner in which weaknesses in collegiality can undermine the legitimacy of particular decisions and, if left unchecked, the legitimacy of the institution. The examples selected are particularly relevant since the issues addressed or raised by the decisions have been such that, on their own terms, challenge the validity of the institution.

\section{Collegiality at the ICC: Cause for Concern?}

\subsection{Formal Collegiality}

Collegiality is evident in the structure of judicial decision-making authority as established by the Rome Statute. ICC judges are divided into three divisions, each dealing with different stages of the judicial process. Within each division, situations and cases are distributed among 'chambers' of judges comprised of either three judges (Pre-Trial and Trial divisions) or five judges (Appeals Chamber). Article 74 requires Trial Chamber decision-making to be undertaken after deliberation, and decisions of chambers are reached by the taking of votes. 
However, as in the context of the Pre-Trial Chamber, decision-making authority can - in regard to some types of decisions - be delegated to a single judge acting on behalf of the Chamber. ${ }^{32}$

Recalling Waters' additional characteristics of collegial decision-making bodies, the composition of the ICC is, in principle, based upon expertise. ${ }^{33}$ However, the ICC Statute like that of other international dispute settlement bodies - adopts a laissez faire approach to stipulating the level of experience and what constitutes 'expertise', deferring to the qualifications for high judicial office required by the national jurisdiction of origin of each judge. ${ }^{34}$ In turn, this provides for a high degree of variance in the professional backgrounds of judges. Like that of other international courts and tribunals, the ICC Statute stipulates that the composition of the Court should be representative of the principal legal systems of the world, ${ }^{35}$ with the ICC Statute further requiring an equitable geographical distribution of judges and that the Court's composition reflects a fair gender balance. ${ }^{36}$ These criteria for selection must be complied with in addition to the qualification criteria. However, in practice the cumulative effect of all these factors along with the politicised process of selecting judges means the level of experience and expertise of ICC judges as appointed is variable, and the impact of these factors upon the quality of the judiciary has been the subject of concern. ${ }^{37}$

\footnotetext{
${ }^{32}$ Article 39(2)(ii) ICC Statute and Rule 7, RPE.

33 Article 36(3)(b) ICC Statute and see, for example, Article 2 ICJ Statute; Article 36 ICC Statute; Article 13bis(1)(c) ICTY Statute; Article 17(3) 'Understanding on rules and procedure governing settlement of disputes', Annex 2, WTO Agreement.

${ }^{34}$ Article 2 ICJ Statute, Article 13 ICTY Statute, Article 17(3) WTO DSU.

${ }^{35}$ Article 9 ICJ Statute, Article 13bis(1)(c) ICTY Statute. Article 36(8)(a)(i) ICC Statute.

${ }^{36}$ Article 36(8)(a)(ii) and (iii) ICC Statute.

${ }^{37}$ An issue afflicting all international courts and tribunals: Ruth Mackenzie, Cesare Romano and Philippe Sands, Selecting International Judges: Principle, Process and Politics (Oxford University Press, Oxford, 2010), p.51 and pp.110-120; Gideon Boas, 'The Case for a New Appellate Jurisdiction for International Criminal Law' in Göran Sluiter and Sergey Vasiliev (Eds) International Criminal Procedure: Towards a Coherent Body of Law (Cameron May, London, 2009), pp.450-451; Peter Murphy and Lina Baddour, 'Evidence and Selection of Judges in International Criminal Tribunals: The Need for a Harmonized Approach' in Elies Van Sliedregt and Sergey Vasiliev (Eds) Pluralism in International Criminal Law (Oxford University Press, Oxford, 2015), pp.368-369 and Jonathan O'Donohue, 'The ICC and the ASP' in Carsten Stahn (Ed) The Law and Practice of the International Criminal Court (Oxford University Press, Oxford, 2015), pp.127-129.
} 
While the appropriateness of these diversity requirements is not questioned, their implications for the strength of behavioural collegiality among judges need to be acknowledged. At the very least, such diversity creates a need for concerted practices and policies designed to inculcate behavioural collegiality to overcome the differences between judges. At the same time, as Section 4 will explain, those differences can themselves limit the range of appropriate policies likely to be effective in promoting behavioural collegiality that are available to the ICC. For now, however, it suffices to note that formally speaking the composition of the ICC possesses the foremost qualities of collegial authority when delegated to a multi-member organisation.

\subsection{Behavioural Collegiality}

From an external perspective, it is difficult to obtain an accurate picture of the strength of the ideational conception of collegiality within an institution, particularly within those institutions where internal deliberations are cloaked, quite appropriately, by the secrecy of deliberations. ${ }^{38}$ Despite this, one method of appraising the strength of the culture of collegiality within the ICC is to reflect upon judicial discourse in the public sphere, that is, as manifested in the published decisions and opinions of the Court's Chambers and individual judges. Collegial decisionmaking does not require a unanimous outcome to the process of deliberation such that disagreement between judges - manifested in both the vote and the existence of any dissenting or separate opinions - is not inconsistent per se with collegiality. However, the nature of those decisions and opinions, as the following will demonstrate, may betray defects in the integrity of the collegial culture. The following sections will discuss three examples where weaknesses in the Court's decision could have been avoided had collegiality been a more dominant culture in the decision-making context in which those decisions had been made. Even if the examples highlighted in this paper are isolated, if allowed to go unchecked such that collegial dysfunction

\footnotetext{
${ }^{38}$ Principle 15, UN Basic Principles on the Independence of the Judiciary, supra note 19.
} 
becomes the norm, this could have more serious - and direct - implications for institutional legitimacy.

\subsubsection{Ruto and Sang: 'No Case to Answer' Decision}

This first example of judicial practice not only demonstrates the manner in which judicial decisions can evidence shortfalls in ideational collegiality but can also suggest defects in the operation of the formal collegial process. In April 2016, Trial Chamber V(A) issued a decision at the request of the defence determining whether - owing to the gradual collapse in the Prosecution case due to ongoing difficulties in securing documentary evidence and witness testimony - the proceedings against defendants Samuel Ruto and Joshua Sang should be terminated. ${ }^{39}$ The decision was the latest in of six years' worth of investigations and proceedings into the 2008 post-election violence in Kenya; proceedings that were shrouded in intense political and legal controversy that tested the relationship between the ICC and African Union states to the limits. During this period, actors hostile to the investigation and prosecution of the defendants in this case and the other arising out of the Kenya situation (namely, that against Uhuru Kenyatta, now President of Kenya) engaged in witness intimidation and bribery. Thus, irrespective of the standpoint adopted - whether in favour of the Court's proceedings in the Kenya situation or against - the credibility of the Court was at this point under considerable pressure. Faced with this, from the perspective of preserving what was left of judicial and institutional validity in respect of the Kenya situation, the conviction with which the Chamber addressed the issue before it was of great importance.

The Chamber decided, by majority, that based on the remaining evidence available there was no case for the accused to answer. Thus, it decided to vacate the charges against the accused and to discharge the accused. ${ }^{40}$ However, in an effort to ensure that the door to future

\footnotetext{
${ }^{39}$ Ruto and Sang, supra note 4.

${ }^{40}$ Ruto and Sang, supra note 4, p.1.
} 
proceedings against the accused in connection to the same situation was not closed, the dispositive paragraph included the observation that the discharge of the accused was 'without prejudice to their prosecution in the future'. ${ }^{41}$ Judge Herrera Carbuccia, dissenting, would have rejected the defence request and would have allowed the case proceed to trial. ${ }^{42}$

While the Trial Chamber's decision raised a myriad of substantive and procedural legal issues (in addition to the not insignificant matters of policy), the focus in this paper is upon the form of the Chamber's decision and its questionable legitimacy, and what says about the culture out of which that particular decision was the outcome. While this focus on form might seem an unlikely point of focus in view of the wider significance of the decision, the focus on form is to demonstrate precisely why form - even in cases as exceptional as this one - matters.

The starting point of the analysis is Article 74(5) of the Rome Statute, which states:

The decision [of the Trial Chamber] shall be in writing and shall contain a full and reasoned statement of the Trial Chamber's findings on the evidence and conclusions. The Trial Chamber shall issue one decision. When there is no unanimity, the Trial Chamber's decision shall contain the views of the majority and the minority. The decision or a summary thereof shall be delivered in open court. ${ }^{43}$

Thus, for decisions of the Trial Chamber to be legal, there must be a single decision of the Chamber that includes the 'full and reasoned statement' of the basis for that decision. Contrary to this, the impugned Decision consisted of a bare statement outlining the majority conclusion - that is, the vacation of the charges and discharge of the accused - with reference to the separate opinions of the two judges who supported that conclusion for the reasons supporting

\footnotetext{
41 Ibid.

${ }^{42}$ Ruto and Sang, supra note 4, Dissenting Opinion of Judge Herrera Carbuccia.

${ }^{43}$ Article 74(5) ICC Statute.
} 
that conclusion. ${ }^{44}$ Furthermore, since those two separate opinions - authored by Judges EboeOsuji and Fremr respectively - offer different bases for their support for the conclusion, and with the third judge, Judge Herrera Carbuccia, dissenting from the Chamber's conclusion, there does not appear to be a single decision of the Chamber in accordance with the requirements of the Statute.

The format of the Chamber's decision may not be quite so objectionable if considered within the context of institutions where decisions are rendered in seriatim, that is, as a collection of the individual opinions of the judges of the court or chamber from which the ratio decidendi of the case is discerned. ${ }^{45}$ However, this approach is clearly inconsistent with both the plain wording of the ICC Statute and the intentions of the drafters as manifested in the wording of Article 74(5) who sought to strike a compromise between those who wished to prohibit judges from expressing their individual views and those who sought to permit them to do so. ${ }^{46}$ For example, the direction in Article 74(3) that Trial Chamber judges 'shall attempt to achieve unanimity in their decision', clearly indicates the emphasis placed upon the norm of unanimity specifically (rather than the more nebulous norm of consensus). ${ }^{47}$ Thus there is an expectation that the Trial Chamber judges would, even in the absence of unanimity to seek as high a degree of agreement as possible. Yet, the bare statement of the Chamber's conclusion contrasted against the three extensively reasoned individual opinions may give the impression of otherwise.

\footnotetext{
${ }^{44}$ Ruto and Sang, supra note 4, p.1.

${ }^{45}$ Ruto and Sang, supra note 4, Reasons of Judge Eboe-Osuji, footnote 213.

46 Otto Triffterer, 'Article 74: Requirements for the decision' in O. Triffterer (Ed) Commentary on the Rome Statute of the International Criminal Court - Observers' Notes, Article by Article (2 ${ }^{\text {nd }}$ Ed Hart, Oxford, 2008), p.1398.

${ }^{47}$ C. Sunstein, 'Unanimity and Disagreement on the Supreme Court' (2013) Preliminary Draft, available at http://papers.ssrn.com/sol3/papers.cfm?abstract_id=2466057, p.6.
} 
Black-letter analysis aside, from both the formal and behavioural perspectives, the decision of the Court and the fact of its apparent inability to arrive at any level of consensus upon the legal basis for the court's ultimate disposition suggests a breakdown in the process of deliberation. ${ }^{48}$ On one level, it does appear that the procedure of majority decision-making consistent with the formal conception of collegiality was followed. Similarly, it is evident - by the fact that each judge issued a detailed individual opinion setting out their individual rationale for voting in favour or against the disposition - that each individual vote was rationally motivated. ${ }^{49}$ However, it cannot be said that the decision of the Chamber represents a rationally motivated consensus ${ }^{50}$ since the deliberations of the Chamber failed to achieve even a minimum degree of consensus upon the basis for its conclusion. Moreover, that each of the judges individually wrote extensive opinions but failed to come together to construct any form of reasoned opinion for the Chamber suggests a weakness in the sense of common endeavour or esprit d'corps that would seem to underpin the impetus towards unanimity and which lies at the heart of the cultural conception of collegiality.

It may be argued that to the extent that there was a breakdown in the collegial culture and process with regard to that particular decision, the account of that breakdown presented here is exaggerated. ${ }^{51}$ After all, the opinions of the majority judges reveal that there was a convergence in opinion between the judges on a majority of issues: they agreed that on the basis of the evidence before them, and owing to the witness interference that had occurred around the case, there was no case for the two defendants to answer. Moreover, they both agreed that the charges

\footnotetext{
${ }^{48}$ However, this is not to advocate the creation of a false appearance of consensus through the delivery of per curiam decisions and the prohibition of individual opinions as is the case at the Court of Justice of the European Union.

${ }^{49}$ Judge Fremr's 'Reasons' ran to 55 pages whereas Judge Eboe-Osuji’s 'Reasons' ran to 196 pages. Judge Herrera Carbuccia's Dissenting Opinion ran to 44 pages.

${ }^{50}$ An observation also made by Judge Herrera Carbuccia in dissent. Ruto and Sang, supra note 4, Dissenting Opinion of Judge Herrera Carbuccia, para.1 (footnote 1).

${ }^{51}$ The author wishes to thank Shezad Charania for raising this point during discussions at the Pluricourts conference, referred to in the author's note at the outset of this paper.
} 
against the accused should be vacated and that proceedings against the accused should not continue. Even further, both agreed that the door to future investigations and prosecutions of the accused in connection to the same events should not be closed. Indeed, the only difference between the two judges was the legal characterisation of this conclusion: whereas Judge EboeOsuji argued in favour of declaring a mistrial - a finding unavailable under the Rome Statute - Judge Fremr stopped short of declaring a mistrial and instead made recourse to the exceptional factual circumstances of the case..$^{52}$

However, precisely because there was such a broad level of agreement between the two judges in the majority, the fact that they still failed to be able to compose a reasoned judgment of the Chamber that represented the extent of their agreement paints an even more troubling picture of the health of collegiality - at least within that particular Chamber. Quite simply - and unnecessarily - the format of the decision itself unnecessarily exaggerated the degree of disagreement between the judges in a moment when a show of solidarity within the Court would have been welcome.

Perhaps this is an isolated incident, attributable to the exigencies of the particular case or the relationship between the particular judges in question. However, looking to the future, lessons can be learned from this situation. Owing to the very nature of the Court's mandate, ICC judges can expect to deal with 'hard cases' that raise challenging issues, legally and politically. In this particular instance the substantive outcome of the Chamber's decision was to the satisfaction of those hostile to the Court. But in future cases it is inevitable that decisions will be made that will be unpopular among powerful stakeholders in the Court's activities. In order to have a chance at withstanding the external challenges to its legitimacy that this environment brings, it

\footnotetext{
${ }^{52}$ Ruto and Sang, supra note 4, Reasons of Judge Fremr, paras.147-148 and Reasons of Judge Eboe-Osuji, para.464(i).
} 
is imperative that the judges are able to, perhaps, put aside their own differences, in the interests of the Court's authority.

\subsubsection{Procedural and Evidential Problem-Solving: Katanga and Ngudjolo}

Whereas the previous example was used to highlight the importance of a strong culture of collegiality in order to effectively buttress against political and/or external threats to its legitimacy, this section will touch upon the importance of a strong culture of collegiality if the Court's judges are to develop a coherent procedural regime that is effective and efficient. Elsewhere in this issue, ${ }^{53}$ Yvonne McDermott has addressed the different methodological approaches to fact-finding and the evaluation of evidence manifested in the jurisprudence of both the ICC and the ad hoc tribunals. In particular, she focussed upon the 'anxiety' among judges with regard to the correct approach towards the evaluation of evidence to be taken as manifested in the dissenting and separate opinions of judges ${ }^{54}$ She identified two broad schools of thought - the 'atomistic' and the 'holistic' approach to the evaluation of evidence - and the approach taken having fundamental consequences for the tribunal's ultimate conclusion upon the individual criminal responsibility of the accused. ${ }^{55}$ At the ICC, these disagreements have manifested themselves in acrimonious exchanges between judges in their individual opinions, the two clearest examples being the dissenting opinion of Judge van den Wyngaert from the Trial Chamber judgment in Katanga (and the response of Judges Cotte and Diarra in their joint separate opinion $)^{56}$ and the joint dissenting opinion of Judges Tarfusser and Trendafilova from the Appeals Chamber judgment in Ngudjolo and Chui. ${ }^{57}$ From the perspective of collegiality,

\footnotetext{
53 Yvonne McDermott, 'Strengthening the Evaluation of Evidence in International Criminal Trials' 17 International Criminal Law Review 1.

${ }^{54}$ Ibid., p.6.

${ }^{55}$ Ibid., p.7.

${ }^{56}$ Katanga, supra note 2.

${ }^{57}$ Ngudjolo, supra note 3.
} 
the problem with these opinions does not lie in fact that disagreement was expressed, but rather in the manner in which that disagreement was expressed.

In Ngudjolo, Judges Tarfusser and Trendafilova - coming from the holistic school of thought - accused the Trial Chamber in its decision upon which they were hearing the appeal as having 'abdicated its paramount responsibility to properly manage the conduct of trial proceedings and ensure their fairness' ${ }^{58}$ They concluded their opinion with the statement that the majority's 'fragmentary approach towards the evaluation of evidence and speculations on its substance create[d] highly alarming precedents in international criminal law capable of compromising the integrity of the proceedings and undermine the perception of the victims and the public that justice is being delivered'. ${ }^{59}$ Similarly - but based upon atomistic school of thought on the evaluation of evidence - Judge van den Wyngaert describing her disagreement with decision of Trial Chamber II as a 'complete dissent' ${ }^{60}$ accused the Chamber in robust language of what she characterised as the unfair and ultra vires exercise of judicial power. ${ }^{61}$ She concluded that what she perceived to be a litany of defects in the Chamber's handling of the case culminated to present 'a case of overwhelming strength against the legality and legitimacy of this judgment' ${ }^{62}$

The disagreements between the judges in both Katanga and Ngudjolo arise out of fundamentally different conceptions of the role of the judge in criminal proceedings, ultimately rooted in differing views of the character and purpose of the criminal trial process. The ICC is a sui generis blend of legal traditions, with identifiable traits from both common law and civil

\footnotetext{
${ }^{58}$ Ibid., Joint Dissenting Opinion of Judges Tarfusser and Trendafilova, para.69.

${ }^{59}$ Ibid., para.69.

${ }^{60}$ Katanga, supra note 2, Dissenting Opinion of Judge van den Wyngaert, para.7.

${ }^{61}$ Ibid., paras.16-49.

${ }^{62}$ Ibid., para. 15.
} 
law jurisdictions and both inquisitorial and adversarial traditions. ${ }^{63}$ This blend was intentional as well as necessary to secure the adoption of the Statute; the representativeness of different legal systems and cultures one basis for the institution's legitimacy. As such, disagreement between judges was a predictable and inevitable consequence of the structure of the Court as designed by the drafters of the Rome Statute. Whereas it may have been (and may still be) expected that the judges would resolve those contradictions and ambiguities through deliberations upon the interpretation of the Statute, the reality has been that the Statute has entrenched the divergence of judicial views by lending support for all positions. ${ }^{64}$ In order to transcend the evident disagreement between judges and to develop a coherent procedural and evidential regime, whether that regime is defined by a pluralism to accommodate such differences, or whether a unified regime is developed, the procedural collegiality manifested in the structure and composition of the judicial chambers must be infused with a strong ethos of collegiality that governs the interactions between judges on a practical basis.

\subsection{Collegiality and the Language of Disagreement}

The two decisions discussed in the previous subsection highlight another important dimension to the relationship between collegiality and institutional legitimacy, as appraised by external actors. ${ }^{65}$ Until now, the focus has been upon the culture of collegiality manifested in one particular deliberative sphere, that is, the internal deliberative context. However, when individual judges are permitted to publish written opinions alongside the judgment or decision

\footnotetext{
${ }^{63}$ Alex Whiting, 'The ICTY as a Laboratory for International Criminal Procedure' in Bert Swart, Göran Sluiter and Alexander Zahar (Eds) The Legacy of the International Criminal Tribunal for the Former Yugoslavia (Oxford University Press, Oxford, 2011), p.83; Kai Ambos, 'International Criminal Procedure: "Adversarial", "Inquisitorial” or Mixed?' 3 International Criminal Law Review (2003) 1; Peter Robinson, 'Ensuring Fair and Expeditious Trials at the International Criminal Tribunal for the Former Yugoslavia' 11 European Journal of International Law (2000) 569; John Jackson, 'Finding the Best Epistemic Fit for International Criminal Tribunals: Beyond the Adversarial-Inquisitorial Dichotomy’ 7 Journal of International Criminal Justice (2009) 17.

${ }^{64}$ Claus Kress, 'The Procedural Law of The International Criminal Court in Outline: An Anatomy of a Compromise' 1 Journal of International Criminal Justice (2003) 603, p.605.

65 Supra note 30.
} 
of the court, as is the case in most international courts and tribunals, the court's decision and the opinions attached contribute to an external discursive sphere, ${ }^{66}$ wherein discourse between judges should be consistent with the cultural norm of collegiality. While individual opinions are not inherently uncollegial, it is possible for judges to undermine collegiality through the manner in which they use their right to issue individual opinions, with implications for judicial authority - both that of the institution and the individual judge(s) in question.

The negative impact of uncollegial behaviour in the form of the content of published individual opinions upon the legitimacy and authority of a judicial institution arises out of the fact that it is conducted in the public sphere. Criticisms of colleagues (as opposed to the opinions held by colleagues) expressed in public not only harm the professional relationship between those individual judges in the same way as criticisms expressed in the private sphere, but public criticisms also affect how others perceive the judges in question. In turn, this affects how external actors appraise the legitimacy, ${ }^{67}$ and ultimately authority, of the institution and the individual judges in question. ${ }^{68}$ This reasons for this are two-fold. The first is substantive and based upon the substantive criticisms and aspersions cast by one colleague against another. When a judge accuses a colleague - or even the institution - of exercising their decisionmaking authority in an improper manner, such criticisms hold greater persuasive force than when those allegations are made by an external actor - for example, an academic, a politician, a practitioner. ${ }^{69}$

\footnotetext{
${ }^{66}$ Judith Resnik and Dennis Curtis, Representing Justice: Invention, Controversy and Rights in City States and Democratic Courtrooms (Yale University Press, New Haven, 2011), p.288; Ian Johnstone, 'Legal Deliberation and Argumentation in International Decision Making' in Hilary Charlesworth and Jean-Marc Coicard (Eds) Faultlines of International Legitimacy (Cambridge University Press, Cambridge, 2010), p.180, Ingo Venzke, How Interpretation Makes International Law: On Semantic Change and Normative Twists (Oxford University Press, Oxford, 2012), p.63.

${ }^{67}$ Venzke, supra note 66, p.63.

${ }^{68} \mathrm{Ibid}$.

${ }^{69}$ Gleider Hernández, The International Court of Justice and the Judicial Function (Oxford University Press, Oxford, 2014), p.122.
} 
The second reason is one of form and concerns the language with which individual judges communicate their views. In order to understand how uncollegial language can undermine judicial authority, it is necessary to appreciate the importance of language to establishing and consolidating judicial authority. Scholars of the rhetorical nature of law draw to our attention how courts 'create by performance [their] own character and role and [establish] a community with others' ${ }^{70}$ They argue that how courts (and by extension, individual judges) say what they do matters as much as what they say. ${ }^{71}$ For example, Peter Goodrich has linked the use of legal rhetoric directly to the capacity of courts to induce the "cooperation and accommodation of social and institutional forces whose real affinities are antagonistic and conflictual', and thus fulfil their dispute resolution function. ${ }^{72}$ Thus, language is not 'merely' cosmetic, but has substantive implications.

In light of this, it becomes easier to appreciate the criticism of the use of particular rhetoric by judges when expressing their disagreement with their colleagues. For example, critics of dissentient practice by judges of the International Court of Justice (ICJ) appear to be less concerned with the revelation of disagreement between the judges of the Court or even the substantive nature of that disagreement. Rather their objections focused upon how language that 'attacked' or was 'critical of' the decision of the Court was considered 'not worthy of members of the highest judicial tribunal' and risked undermining the prestige and dignity of the Court. ${ }^{73}$ Even those judges who have exhibited a favourable attitude towards dissenting and

\footnotetext{
${ }^{70}$ William Boyd White, Justice as Translation: An Essay in Cultural and Legal Criticism (University of Chicago Press, Illinois, 1990), 102 cited by A. Sarat and T. Kearns, 'Editorial Introduction' in A. Sarat and T. Kearns (Eds) The Rhetoric of Law (University of Michigan Press, Michigan, 1994), p.9.

${ }^{71}$ Sarat and Kearns, supra note 70, p.9.

${ }^{72}$ Peter Goodrich, Legal Discourse: Studies in Linguistics, Rhetoric and Legal Analysis (MacMillan Press, London, 1987), p.86. Similarly, Jan Broekman, 'Communicating Law' in David Nelken (Ed) Law as Communication (Dartmouth Publishing, Aldershot, 1996), pp.47-48.

${ }^{73}$ Ijaz Hussain, Dissenting and Separate Opinions at the World Court (Martinus Nijhoff, Leiden, 1984), p.40; Manley Hudson, 'The Twenty-Eighth Year of the World Court' (1950) 44 American Journal of International Law 1, pp.20-21; Edward Hambro, 'Dissenting and Individual Opinion in the International Court of Justice'17 Heidelberg Journal of International Law (1956-1957) 230, p.244.
} 
separate opinions have maintained that there is 'no excuse for intemperateness. It is possible to make a protest with vigour and yet with the elegant serenity customary in learned judicial discourse ${ }^{74}$ Writing from a domestic law perspective, William Ross has described how 'civility is one of the hallmarks of the judicial temperament' such that judicial incivility is more concerning than incivility within other branches of government. ${ }^{75}$ Going further, in the context of the ICJ, it has been suggested that the use of polite and courteous - and ultimately collegial - language by judges is an aspect of the qualities of 'integrity and propriety' that are implicit in the requirement that ICJ judges be 'persons of high moral character'. ${ }^{76}$

With this in mind, we can consider the rhetoric of dissent utilised by the dissenting judges in Ngudjolo and Katanga canvassed in Section 3.2.2. This rhetoric may be understood as not only a symptom of the breakdown in the collegial process as discussed previously, but as this subsection has explained it can also itself be a cause of further deterioration in the collegial culture. This sub-section has also explained how the use of such robust language to express disagreement can have a direct - and negative - impact upon the perceived legitimacy and, in turn, authority of the judicial institution. While the present author would not go so far as to stipulate what is or is not appropriate judicial rhetoric in the context of the ICC system, at the very minimum it is nevertheless important to acknowledge the consequences of the choice of language used by judges.

\footnotetext{
${ }^{74}$ Mohamed Shahabuddeen, International Criminal Justice at the Yugoslav Tribunal (Oxford University Press, Oxford, 2012), p.78 (emphasis added).

${ }^{75}$ William Ross, 'Civility Among Judges: Charting the Boundaries of Proper Criticism by Judges of Other Judges' 51 Florida Law Review (1999) 957, pp.957-8.

${ }_{76}$ Mariano Anzar-Gómez, 'Article 2' in Andreas Zimmermann et al, The Statute of the International Court of Justice ( $2^{\text {nd }}$ Ed. Oxford University Press, Oxford, 2012), p.244.
} 


\section{Developing Collegiality: Lessons from Elsewhere?}

If a strengthened culture of collegiality at the ICC can enhance the legitimacy of judicial decision-making (both as a matter for form and quality), it might be asked what measures ICC judges can adopt in order to deepen the culture of collegiality at the ICC. Culture is an inherently contextual and complex phenomenon: ${ }^{77}$ the cultivation of any culture, institutional or otherwise, is an organic process that takes time. This does not mean, however that the substantive attributes of a culture are beyond the control of actors; policies and practices can be undertaken in order to promote the cultivation of a culture with specific attributes. Accordingly, it might be considered useful to reflect upon how other judicial institutions faced with similar challenges - have promoted the culture of collegiality, and it might be asked whether it is appropriate to "transplant' ${ }^{78}$ any practices and policies adopted by those institutions into the ICC context.

One institution to which it may be tempting to turn for inspiration is the ICJ. Like the ICC, the ICJ judiciary is comprised of judges from diverse professional and cultural backgrounds. As with the ICC (and perhaps even more so), the political, geographical, professional and epistemological diversity of the ICJ judges is lauded as one of its principal legitimising attributes. ${ }^{79}$ The inevitable disagreement between judges that results from these viewpoints is manifested in the Court's jurisprudence, which is characterised by the plurality of opinions that invariably accompany the judgment of the Court. Yet, over the course of the ICJ's 95-year history both in its current form and in its previous incarnation as the Permanent Court of International Justice, the ICJ has developed certain formal practices designed to cultivate robust collegiality. However, the ICJ is not taken to be the perfect example of collegiality in practice.

\footnotetext{
${ }^{77}$ Supra, Section 2.

${ }^{78}$ Nelken and Feest, supra note 5.

${ }^{79}$ Georges Abi-Saab, 'The International Court as a World Court' in Vaughan Lowe and Malgosia Fitzmaurice (Eds) Fifty Years of the International Court of Justice (Cambridge University Press, Cambridge, 1996).
} 
It is certainly likely that divisions and internal politics may affect the nature and outcome of internal deliberations at the ICJ and there may well be uncollegial practice. Moreover, as the following discussion will explain, the suggestions offered are not without their own difficulties if considered from the perspective of the ICC.

The first policy might be to institute a more formalised process of deliberation and decisionmaking; one that supplements that formal conception of collegiality embodied by the Rome Statute's provisions governing the structure of decision-making. At the ICJ, the formal internal judicial procedure requires individual judges to produce and circulate written 'notes' that explain their views on the case at hand once all submissions by the parties have been made and preliminary oral deliberations have been undertaken. ${ }^{80}$ These written notes in turn provide the basis of the oral discussions and deliberations, with all judges having had the opportunity to read and reflect upon the different judicial views prior to those deliberations. ${ }^{81}$ The process of these oral exchanges is formally structured to encourage full participation by all members of the Court, ${ }^{82}$ with judges required, in reverse order of seniority, ${ }^{83}$ to present to their colleagues their views on the case and to respond to questioning by those colleagues. ${ }^{84}$ Whereas the notewriting and circulating process may encourage judges to formulate and entrench their views prior to the Court's deliberations at the ICJ ${ }^{85}$ the views of all ICJ judges are subject to

\footnotetext{
${ }^{80}$ Article 3 and Article 4, Resolution Concerning The Internal Judicial Practice of the Court, Adopted on 12/04/1976 ('ICJ Resolution'); elaborated upon by Robert Jennings, The Internal Judicial Practice of the International Court of Justice 59 British Yearbook of International Law (1988) 32, and Hugh Thirlway, 'The Drafting of ICJ Decisions: Some Personal Recollections and Observations' 5 Chinese Journal of International Law (2006) 15, p.17.

${ }^{81}$ Article 5 ICJ Resolution, elaborated upon Jennings (1988) n. 80.

${ }^{82}$ Kenneth Keith, 'The International Court of Justice: Reflections on the Electoral Process' 9 Chinese Journal of International Law (2010) 49, pp.73-74.

${ }^{83}$ Ibid.

${ }^{84}$ Robert Jennings, 'The Collegiate Responsibility and the Authority of the International Court of Justice' in Yoram Dinstein (Ed) International Law at a Time of Perplexity (Martinus Nijhoff, Leiden, 1989); Jennings, supra note 80 .

${ }^{85}$ Hernández, supra note 69, p.107 citing Daniel Terris, Cesare Romano and Leigh Swigart, The International Judge: An Introduction to the Men and Women Who Decide the World's Cases (Oxford University Press, Oxford, 2007), p.39 and Sture Petrén, 'Forms of Expression of Judicial Activity' in Leo Gross (Ed), The Future of the International Court of Justice (Volume II) (Oceana Publications, New York, 1976), p.448-449.
} 
examination and critique during the oral deliberations. Once the drafting has commenced the process of reading the draft judgment and the circulation and reading of draft additional opinions constitutes an ongoing process of deliberation, ${ }^{86}$ whereby both the Court's draft judgment and the draft opinions are the subject of critical reflection, review and amendment in light of each other. ${ }^{87}$ Thus, there is a rigorous formal procedure designed to require individual participation in deliberation, one that is complemented by informal discussions between judges as the formal process of the Court's deliberation and drafting proceeds.

Deliberative procedure within the international criminal tribunals is markedly different and less formally prescribed. While all judges are clearly expected to contribute to deliberations upon the cases to which they are assigned, there is no formalised procedure such as that at the ICJ compelling it. ${ }^{88}$ Deliberations are conducted orally or through the exchange of informal notes, and once it is clear where the majority (in the absence of unanimity) lies, responsibility for drafting the Chamber's decision is assumed by that majority. ${ }^{89}$ Whereas at the ICJ, the process of deliberation formally commences once all submissions have been made and hearings have been conducted, deliberations within the international criminal tribunals - given the length and complexity of the cases - is an ongoing process from the commencement of proceedings before the given Chamber through to the delivery of the Chamber's decision. ${ }^{90}$

It is for this reason - namely, the sheer length and complexity of cases - that adopting a highly formalised approach to deliberation and decision-making such as that at the ICJ would not be practicable for the ICC. The length of ICC proceedings is already the subject of significant criticism and the adoption of an approach inspired by the ICJ would like hinder the expediency

\footnotetext{
${ }^{86}$ Jennings, supra note 84; Jennings, supra note 80.

${ }^{87}$ Article 7 and Article 8 ICJ Resolution, supra note 80.

${ }^{88}$ Marko Divac Öberg, 'Processing Evidence and Drafting Judgments in International Criminal Trial Chambers' 23 Criminal Law Forum (2013) 113, p.123 et seq.

${ }^{89}$ Ibid.

${ }^{90}$ Ibid.
} 
of deliberations. On a practical level, the internal organisational structure (as opposed to the sequencing of hearings, deliberations, decision-making and decision-drafting) might make a direct transposition of some of the more formalised processes and system of seniority from the ICJ to the ICC more difficult. The ICJ sits in plenary and therefore it is easier to enforce and reinforce these systems and procedures. By contrast, the Chamber configuration of the ICC with judges sitting in parallel to each other inevitably makes this more difficult. However, this in itself should not discourage the exploration of other options that may be more appropriate to the ICC but which serve a similar purpose.

A second strategy might be to accentuate the responsibility of the Court's President for overseeing the institution's operational culture. One former ICJ President has explained the manner in which the President can set the tone for decision-making and the prioritisation placed upon achieving consensus or unanimity. ${ }^{91}$ In turn, depending upon the approach, this can encourage or discourage the use of additional opinions. ${ }^{92}$ Again, the ability of the President of the Court to enforce a common culture or practice may be easier in an institution such as the ICJ where judges sit in a singular plenary configuration, of which the President is always the most senior member. ${ }^{93}$ At the ICC, the multiple divisions and Chambers make it difficult to obtain consistency. Yet, if there were to be initiatives at the ICC to enhance collegiality, logically it would seem that the Presidency would be the most appropriate organ to drive such initiatives. $^{94}$

\footnotetext{
${ }^{91}$ G. Guillaume, 'Cultures Juridiques et Delibere Judicaire' in Societe Française Pour le Droit International, Droit International et Diversité des Cultures Juridiques/International Law and Diversity of Legal Cultures (Pedone, Paris, 2008) pp.401-402.

${ }^{92}$ Ibid.

${ }^{93}$ However, it is possible for the Court to sit in a Chamber formation rather than a full plenary. Articles 26 and 27 ICJ Statute.

${ }^{94}$ Terris, Romano and Swigart, supra note 85, p.205.
} 
Another strategy suggested by Göran Sluiter might be that the ICC adopt a document akin to the ICJ's Resolution on Internal Judicial Practice, ${ }^{95}$ designed to reinforce the formal process of deliberation, decision-making and drafting and strengthen the sense of internal collegiality and discipline. ${ }^{96}$ While there is a general disinclination towards the adoption of a judicial codes of conduct in the context of international justice which may fuel scepticism as to the utility of such a Resolution at the ICJ in the absence of a mechanism of enforcement, ${ }^{97}$ the process of drafting such a resolution may be of utility. Even if unenforceable, an inclusive process of drafting will raise the profile of collegiality, and the existence of the resolution may serve to remind judges and those working within the institution of the importance of judicial discipline and collegiality which might easily be overlooked in the heat of the strong disagreement.

Finally, one informal mechanism by which to encourage the development of an institutional culture is for judges (or former judges) to write about their experiences on the Court extrajudicially. There is a long tradition of ICJ judges of doing this, both as sitting judges and once they have left the Court. ${ }^{98}$ This practice reinforces the sense of institutional culture and raises awareness of it and its importance, both internally and externally. Although judges - both ICJ judges and domestic judges - have addressed the subject of collegiality within the institution, it is understandable why the matter might be considered a sensitive topic to comment upon. Judges who do write about collegiality within their institution are likely to stress what

\footnotetext{
95 Supra note 80.

${ }^{96}$ Göran Sluiter, 'Unity and Division in Decision Making - The Law and Practice on Individual Opinions at the ICTY' in Swart, Sluiter and Zahar, supra note 63, pp.200-201.

${ }^{97}$ Terris, Romano and Swigart (2007) n.85, pp.94-5 and Detlev Vagts, 'The International Legal Profession: A Need for More Governance?’ 90 American Journal of International Law (1996) 250, p.251.

98 Gerald Fitzmaurice, 'The Law and Procedure of the International Court of Justice: General Principles and Substantive Law' 27 British Yearbook of International Law (1950) 1, pp.1-2; Jennings, supra note 84, p.348; Jennings, supra note 80; Mohamed Shahabuddeen, Precedent in the World Court (Cambridge University Press, Cambridge, 1996), p.177 et seq; Mohammed Bedjaoui, 'The Manufacture of Judgments of the International Court of Justice' 3 Pace Yearbook of International Law (1991) 29, Gilbert Guillaume, 'Les Declarations Jointes aux Decisions de la Cour Internationale de Justice' in Calixto Armas Barea et al (Eds), Liber Amicorum 'In Memoriam of Judge José Maríe Ruda (Martinus Nijhoff, Leiden, 2000); Guillaume, supra n.91 ; Nagendra Singh, The Role and Record of the International Court of Justice (Martinus Nijhoff, Leiden, 1989); Rosalyn Higgins, 'Reflections from the International Court' in Martin Shaw (Ed) International Law ( $2^{\text {nd }}$ Ed Oxford University Press, Oxford, 2006), p.4.
} 
collegiality within that institutional context means, explain why it is important and perhaps highlight evidence of best practice. It is unlikely that a judge will explicitly criticise the institution or individual colleagues for uncollegial behaviour in public; in many respects that in itself would be uncollegial behaviour. However, general accounts that describe the extant institutional culture (or at least, the desired institutional culture) are valuable as they can inform potential and incoming judges of the existence and importance attached to institutional culture and collegiality within the institution that they are joining, thereby contributing to the socialisation of newcomers into the institution. ${ }^{99}$ Once members of the Court, this body of literature provides a reminder or guidance of what culture they have joined and with what ethos they are expected to discharge their functions. At the same time, in some respects the background of ICJ judges is not quite as diverse as that at the ICC. In the most part, ICJ judges are familiar with the discipline of international law - whether coming from academic, practitioner, or diplomatic (or often a mixture of all three) backgrounds - and are therefore more likely to be familiar with the field of literature, having read the same leading journals and leading texts, for example. ${ }^{100}$ By contrast, at the ICC, while some judges may have experience in international (criminal) law having served as counsel or as judges in other international (criminal) courts and tribunals, others may join the Court after lengthy careers as domestic criminal judges or domestic prosecutors. Accordingly, they are unlikely to be familiar with the same field of professional and scholarly literature as that of their counterparts, which may limit the effectiveness of such writings.

\footnotetext{
${ }^{99}$ John Bell, Judiciaries within Europe: A Comparative Review (Cambridge University Press, Cambridge, 2006); Nuno Garoupa and Tom Ginsburg, 'Reputation, Information and the Organization of the Judiciary' (2009) 4 JCL 228, p.251; Paul Wice, Judges and Lawyers: The Human Side of Justice (HarperCollins, London, 1991), pp.1819. On informal socialisation into the judicial culture within a particular judicial system, see Penny Darbyshire, Sitting in Judgment: The Working Lives of Judges (Bloomsbury, London, 2011).

${ }^{100}$ At the ICJ, there is a relatively closed and small community of judges and legal counsel and many of ICJ judges have served as counsel before the ICJ before joining the Court. Thus, the community of lawyers and judges in the context of the ICJ is particularly tight-knit with a strong sense of culture. Keith Highet, 'A Personal Memoir of Eduardo Jiménez de Aréchaga’ 88 American Society of International Law Proceedings (1994) 577 at p.579.
} 
David Nelken has cautioned that the success of legal transplants depends on the 'relationship or the "fit" between law and society' as well as between the transplanted and the extant legal system, and the degree to which the transplanted law penetrates society'. ${ }^{101}$ This section has showed that the same can be said when considering legal transplants in the across institutions, rather than societies. What may be learned from the ICJ's practices if policies and practices are to be developed, then the primary actors - clearly - must be the judges themselves. As a matter of preserving judicial independence and impartiality, judicial autonomy is paramount meaning that measures affecting how judges conduct their deliberations and decision-making cannot be dictated or imposed upon judges, such as by the Assembly of States Parties. The judges themselves must undertake any initiatives undertaken to the end of strengthening collegiality. From a practical perspective, it is those who are closely involved in the process of deliberations or decision-making and who are aware of the true culture within the institution who can identify the root causes of any weaknesses in the culture of collegiality (to the extent that there are any) and to prescribe, based upon their experiences working within the extant culture, the solutions most likely to be effective in addressing those issues.

\section{Concluding Remarks}

The ICC is a young institution, and the imbedding of an institutional culture takes time. At the ICC this is particularly so, where unlike at the ICJ, judges have non-renewable terms of office thus hampering the development and retention of institutional memory. Given the age of the Court, it would be surprising if there already existed a robust institutional culture - whether that is one of collegiality or otherwise. Therefore, to the extent that there is a question-mark over the strength of the collegial norm within the ICC as discussed in this article, it can be considered not too concerning. Moreover, many of the difficulties faced, or potentially faced,

\footnotetext{
${ }^{101}$ David Nelken, ‘Towards a Sociology of Legal Transplantation' in Nelken and Feest, supra note 5, p.14.
} 
by the ICC are not unique to it: for example, balancing judicial individuality and independence with the needs of the institution and overcoming the particular challenges presented when dealing with elites such as judges are both issues faced by all judicial systems and institutions. However, the fundamental argument remains: while the ICC and its judges continue to grapple with the myriad of challenges that it faces as they seek to develop an effective and efficient procedural regime within the Court, they should not overlook the importance of - in the course of doing so - nurturing the development of a robust collegial culture. 